\author{
KATARZyna OGNiK, EwELINA ChOLEWIŃSKA \\ Katedra Biochemii $i$ Toksykologii \\ Wydział Biologii, Nauk o Zwierzetach i Biogospodarki \\ Uniwersytet Przyrodniczy $w$ Lublinie \\ Akademicka 13, 20-950 Lublin \\ E-mail:kasiaognik@poczta.fm
}

\title{
BIOMARKERY WYKORZYSTYWANE W OCENIE OKSYDACYJNYCH USZKODZEŃ BIAŁEK
}

\section{WSTEP}

Stres oksydacyjny występuje w komórce, gdy dochodzi do zaburzeń równowagi między procesami anty- i prooksydacyjnymi. Nadmierna produkcja reaktywnych form tlenu $i$ azotu oraz zbyt mała ilość substancji antyoksydacyjnych prowadzi do przewagi procesów prooksydacyjnych (KAROLKIEWICZ 2011). Jeśli stan ten utrzymuje się krótko - stymuluje reakcje obrony antyoksydacyjnej organizmu. Przykładem może być produkcja reaktywnych form tlenu przez makrofagi, stanowiaca jeden $z$ mechanizmów obronnych w infekcji bakteryjnej (GRIMSRUD i współaut. 2008). Długotrwały stres oksydacyjny może z kolei prowadzić do uszkodzenia komórek, zwłaszcza utleniania białek, węglowodanów i lipidów (KAROLKIEWICZ 2011).

Ocena nasilenia stresu oksydacyjnego umożliwia określenie stopnia uszkodzeń komórek, a także związanych $z$ nimi chorób, takich jak choroba Alzheimera, miażdżyca, zaćma, astma czy obturacyjna choroba płuc. Bezpośrednia analiza ilości reaktywnych form tlenu i azotu jest zadaniem bardzo trudnym, dlatego w ocenie nasilenia stresu oksydacyjnego częściej wykorzystuje się zwiąki powstajace w wyniku reakcji wolnych rodników ze składnikami komórek organizmu. Każda $z$ substancji utleniających powoduje bowiem powstanie charakterystycznych dla niej markerów, a wśród nich specyficznych modyfikacji białek czy produktów ubocznych reakcji. Sa one o wiele trwalsze od wolnych rodników, a przez to łatwiejsze do analizy. Ponadto, dostarczaja informacji na temat konsekwencji uszkodzeń dla organizmu (DALlE-DONNE i współaut. 2005).

\section{MARKERY PEROKSYDACJI BIAŁEK POWSZECHNIE WYKORZYSTYWANE W DIAGNOSTYCE STRESU OKSYDACYJNEGO}

Markerami uszkodzeń białek sa produkty ich utleniania, powstajace w wyniku stresu oksydacyjnego. Produkty oksydacji czasteczek biologicznych moga wykazywać specyficzność tkankową i organellową. Łatwość wykrycia swoistego śladu, pozostawionego w postaci zmodyfikowanych składników komórki, może stanowić informację o chemicznej i biologicznej naturze utleniacza, a także pomóc w diagnostyce różnych chorób (DALLE-DONNE i współaut. 2005).

Białka moga być utleniane bezpośrednio przez ROS (reaktywne formy tlenu) lub pośrednio w reakcjach ze zwiazkami powstałymi w wyniku działania stresu oksydacyjnego. Wśród substancji wykazujacych zdolność do utleniania białek wymienia się przede wszystkim: wodoronadtlenki, kwas podchlorawy, kwas bromawy, metale ulegajace redukcji np. żelazo i miedź, nadtlenoazotyn, wolne rodniki, a także produkty peroksydacji lipidów i utlenione aminokwasy. Zwiazki te wykazuja odmienny sposób działania, moga też przyłączać się do różnych końców łańcucha polipeptydowego. W zwiazku $z$ tym wyróżnia się wiele zróżnicowanych mechanizmów utleniania białek oraz powstajacych produktow reakcji (SHACTER 2000). Do najważniejszych reakcji oksydacji białek zalicza się nitrowanie 
reszt aminokwasów cyklicznych, utlenianie grup tiolowych $(-\mathrm{SH})$, utlenianie reszt cysteiny $i$ metioniny, tworzenie pochodnych karbonylowych niektórych aminokwasów, fragmentację łańcucha polipeptydowego, powstawanie wiazań krzyżowych, tworzenie wodoronadtlenków białek oraz przyłaczanie grupy hydroksylowej do aminokwasów cyklicznych i alifatycznych (PONCZEK i WACHOWICZ 2005).

Wpływ stresu oksydacyjnego na organizm ocenia się głównie na podstawie powstajacych substancji oraz uszkodzeń w komórkach. Markery białkowe należą do najlepszych, ponieważ białka występuja w każdej komórce, a produkty ich utleniania sa stosunkowo trwałe i łatwe do analizy, nawet przy wykorzystaniu prostych metod laboratoryjnych. Dodatkowo, utlenianie białek najczęściej wiąże się z utrata lub zmiana ich funkcji. Badając uszkodzenia białek możemy ustalić jaki czynnik wywołał zmiany, ponieważ każdy $z$ nich powoduje powstanie specyficznej modyfikacji. Zmodyfikowane białka gromadzone sa w organizmie, co umożliwia ich analizę i określenie stopnia narażenia na wiele schorzeń. Wśród najważniejszych biomarkerów wykorzystywanych w ocenie oksydacyjnych uszkodzeń białek wymienia się pochodne karbonylowe, 3-nitrotyrozynę, S-nitrotriazole, kynureninę, 3-chlorotyrozynę, bromotyrozynę, sulfotlenek metioniny, dityrozynę, oksohistydynę oraz tzw. zaawansowane produkty oksydacji białek (SHACTER 2000).

\section{GRUPY KARBONYLOWE}

Grupy karbonylowe (aldehydowe lub ketonowe) przyłączają się do bocznych łańcuchów białka. Powstajace związki sa bardzo trwałe, co umożliwia ich analizę. Gromadzące się w organizmie trwałe pochodne karbonylowe uszkodzonych białek, sa cennymi markerami, pozwalajacymi na określenie stopnia nasilenia procesów utleniania białek (DALle-Donne i współaut. 2005). Pochodne karbonylowe powstają najczęściej wskutek utleniania reszt aminokwasów, zwłaszcza proliny, argininy, lizyny i treoniny. Niekiedy ich synteza możliwa jest również wskutek rozszczepienia łańcucha peptydowego, alfa-amidacji lub utleniania prowadzacego do powstania grup alfa-ketoacylowych na N-końcu białka (DALLE-DONNE i współaut. 2003). Karbonylacja białek zachodzi również $\mathrm{w}$ reakcjach $\mathrm{z}$ produktami peroksydacji lipidów, takimi jak: dialdehyd malonowy, akroleina (2-propenal) i 4-hydroksynonenal, oraz w efekcie glikozydacji, tj. reakcji grupy aminowej lizyny $z$ cukrami redukujacymi lub produktami ich utleniania. Powstałe w wyniku tych reakcji grupy karbonylowe moga reagować $z$ grupami aminowymi lizyny, tworzac wiazania krzyżowe w obrębie danego białka i pomiędzy cząsteczkami różnych białek (DALLE-DONNE i współaut. 2005).

Ponieważ pochodne karbonylowe sa stosunkowo trwałe, ich analiza jest łatwiejsza niż w przypadku analizy innych modyfikacji białek wywołanych przez stres oksydacyjny. Dotychczas opisane metody oznaczania pochodnych karbonylowych opieraja się przede wszystkim na reakcji badanych zwiąków $z$ DNPH (2,4-dinitrofenylohydrazyna) i powstaniu DNP (2,4-dinitrofenyl), które dają się łatwo wykryć przy pomocy technik spektrometrycznych (DALLE-DONNE i współaut. 2003). Pochodne karbonylowe można oznaczać na płytkach ELISA metodami immunohistochemicznymi i immunoenzymatycznymi $z$ wykorzystaniem odpowiednich dla metody przeciwciał (SHACTER 2000).

\section{3-Nitrotyrozyna}

Proces nitrowania tyrozyny cechuje niska wydajność, gdzie zaledwie 1-5 reszt na 10.000, ulega reakcji. Jednym $z$ najważniejszych czynników przyczyniających się do powstania 3-nitrotyrozyny jest nadtlenoazotyn. Zwiazek ten powstaje w wyniku reakcji tlenku azotu i anionorodnika ponadtlenkowego. Zdolności nitrujące wykazuje także chlorek nitrylu $\left(\mathrm{NO}_{2} \mathrm{Cl}\right)$. Stąd też nitrotyrozyna uważana jest za marker stresu nitrozacyjnego wynikajacego $z$ aktywności reaktywnych form azotu. Uszkodzone w ten sposób białka lokalizuja się głównie w miejscach gromadzenia się lub powstawania czasteczek nitrujących. Nasilenie procesów nitracyjnych towarzyszy szczególnie często chorobom zwiazanym neurodegeneracyjnym, a także procesom apoptozy czy starzenia komórkowego (SzUBA i WoJTASZEK 2010).

Aminokwas tyrozyna występuje w wielu białkach enzymatycznych, zatem nitrowanie reszt tyrozynowych powoduje zahamowanie pełnionych przez nie funkcji (KOŁODZIEJCZYK 2010). Nitracja najczęściej zachodzi w części hydrofilowej białka. Istotne znaczenie w tym przypadku ma również struktura białka, obecność aminokwasów kwaśnych, a także stężenie $\mathrm{CO}_{2}$ i $\mathrm{pH}$. 3-Nitrotyrozyna jest modyfikacja stosunkowo trwała, zachodzaca w szerokim zakresie temperatury i pH. Białka zawierajace zmodyfikowane reszty tyrozyny moga ulegać agregacji lub degradacji. Ostatnie badania wskazuja na występowanie w organizmie ludzi i zwierzat mechanizmów odpowiedzialnych za denitrację 3-nitrotyrozyny, powiazane m.in. $z$ działaniem wybranych enzymów obrony antyoksydacyjnej, np. peroksydazy glutationowej (SzUBA i WOJTASZEK 2010).

Najbardziej powszechnymi sposobami wykrywania 3-nitrotyrozyny sa czułe metody immunoenzymatyczne (ELISA), które wykorzystuja przeciwciała anty-nitrotyrozynowe. Nie- 
kiedy stosuje się także chromatografię cieczowa do identyfikacji modyfikowanych białek lub gazowej do analizy wolnej 3-nitrotyrozyny (KoŁODZIEJCZYK 2010). Po rozdziale chromatograficznym mieszaniny białek, otrzymaną próbę analizuje się najczęściej za pomoca tandemowej spektrometrii mas. Najnowsza technika stosowana $\mathrm{w}$ analizie zawartości 3-nitrotyrozyny jest jednak znakowanie nitrowanych miejsc przy pomocy chlorku dansylu lub biotyny, które umożliwiają wykrycie modyfikacji w mieszaninach złożonych $z$ wielu białek. Metoda ta opiera się na bezpośredniej identyfikacji znakowanych, a następnie strawionych peptydow przy pomocy spektrometrii mas. Zmodyfikowane białka rozpoznaje się na podstawie porównania jonu prekursorowego oraz analizy $\mathrm{MS}^{3}$ i obserwacji produktów fragmentacji właściwych dla dansylu lub biotyny. Niewatpliwa zaleta tej metody, wyróżniajaca ja na tle innych dotychczas stosownych technik wykrywania nitrotyrozyny, jest jej wysoka czułość. Dansylowe pochodne aminokwasów, wykazujące silną fluorescencję w świetle nadfioltowym, można bowiem wykryć już w ilościach rzędu $10^{-10}-10^{-9}$ mola (SZUBA i WOJTASZEK 2010).

\section{S-nitrozotiole}

S-nitrotriazole powstaja w wyniku stresu nitrozacyjnego. Kation $\mathrm{NO}^{+}$przyłącza się do reszty aminokwasu, który posiada grupę tiolowa -SH. Tworzenie S-nitrozotioli zachodzi z dużą szybkością, zawsze w określonym miejscu białka, przy konkretnym aminokwasie zawierającym siarkę, otoczonym aminokwasami kwaśnymi (WŁODEK i ICIEK 2003). S-nitrozotiole, np. S-nitrozoglutation czy S-nitrozocysteina, i nitrozobiałka mają zdolność przenoszenia grupy NO. Moga one uwalniać w warunkach fizjologicznych jony $\mathrm{NO}^{+} \mathrm{i} \mathrm{NO}^{-}$. Umożliwia to zachodzenie transnitrozylacji, czyli nitrozylacji kolejnej grupy -SH oraz zmiany funkcji białka (SzUBA i WOJTASZEK 2010).

S-nitrozylacja pełni ważna funkcję w organizmie, bowiem dotyczy wielu białek bioracych udział w reakcjach enzymatycznych metabolizmu podstawowego, metabolizmu siarki, glikolizy, a także $\mathrm{w}$ białkach pełniących w komórkach funkcje strukturalne. W zależności od tego jakie aminokwasy otaczają resztę zawierajacca grupę - $\mathrm{SH}$, nitrozylacja może kończyć się powstaniem stabilnych nitrozotioli białek lub zachodzić dalej, skutkując powstaniem m.in. disiarczku białka i reszty nitroksylowej (WŁODEK i ICIEK 2003).

S-nitrozotiole sa stosunkowo trwałe, jednak w organizmach żywych obecne sa enzymy odpowiedzialne za ich rozkład. Głównym nitrozotiolem wytwarzanym w ustroju jest S-nitrozoglutation, a enzymem rozkładajacym go jest reduktaza nitrozo glutationowa (SzUBA i WOJTASZEK 2010).

Wykrywanie S-nitrozotioli i określanie ich stężenia w badanym materiale jest stosunkowo łatwe. $Z$ powodzeniem sprawdzaja się tutaj zarówno proste metody spektrometryczne, jak i bardziej skomplikowane techniki chromatograficzne i immunochemiczne, umożliwiające wykrycie zmienionych białek (SzUBA i WOJTASZEK 2010). Do wykrywania S-nitrozotioli przydatna okazuje się także spektrometria mas, bowiem reszta NO powoduje zmianę masy peptydu, a to $z$ kolei wiaże się $z$ różnica $\mathrm{w}$ widmie masowym białek natywnych w stosunku do ich zmodyfikowanych odpowiedników (DALLE-DONNE i współaut. 2005).

\section{Kynurenina}

Rodnik tryptofanowy, reagując $z$ nadtlenkami lub tlenem czasteczkowym, sprzyja powstawaniu wodoronadtlenków, które w odpowiednich warunkach moga przekształcać się w N-formylokynureninę (NFK) i kynureninę. Zwiazki te wykorzystuje się jako biomarkery uszkodzeń białek, w skład których wchodza reszty tryptofanu (EHRENSHAFT i współaut. 2015).

Ze względu na fakt, że rodniki hydroksylowe moga atakować pierścień aromatyczny, podczas utleniania tryptofanu dochodzi do powstania pochodnych hydroksylowych oraz pierścienia pirolowego, a następnie utworzenia $\mathrm{N}$-formylokynureniny oraz kynureniny. Zmiany w strukturze tryptofanu moga prowadzić do utraty funkcji białek (EHRENSHAFT i współaut. 2015).

Tryptofan $z$ powodzeniem wykrywany jest za pomoca zmiany fluorescencji. Produkty jego utleniania: kynurenina i N-formylokynureinina, pochłaniaja co prawda krótsze fale świetlne, jednak niemożliwe jest ich wzajemne rozróżnienie (EHRENSHAFT i współaut. 2015). W związku $z$ tym, w celu ich oznaczenia stosuje się jedna $z$ technik spektroskopii mas (jonizacja przez rozpylanie w polu elektrycznym; ang. electrospray ionization, ESI), która umożliwia wykrywanie przyrostu masy adduktów (DALLE-DONNE i współaut. 2005). Połaczenie spektrometrii mas z chromatografia cieczową umożliwia także określenie miejsca utlenienia, jeśli takich modyfikacji w białku jest niewiele. Obecność $\mathrm{N}$-formylokynureniny można również wykryć metodami immunodetekcji $z$ użyciem przeciwciał (EHRENSHAFT i współaut. 2015).

\section{3-Chlorotyrozyna}

W wyniku działania kwasu podchlorawego w organizmie powstaja 3-chlorotyrozyna i 3,5-dichlorotyrozyna. Kwas podchlorawy jest produkowany przez neutrofile i monocyty podczas obrony organizmu przed bakteria- 
mi. Powstaje w reakcji nadtlenku wodoru z chlorem, katalizowanej przez mieloperoksydazę. Chlorotyrozyna powstaje in vivo jedynie pod wpływem kwasu podchlorawego, dlatego jest najlepszym markerem modyfikacji białek wywoływanych przez ten kwas (CHAPMAN i współaut. 2000).

Do najczęściej stosowanych metod detekcji 3-chlorotyrozyny zalicza się chromatografię gazowa (GC), chromatografię cieczowa (LC) i wysokosprawna chromatografie cieczowa. Niekiedy metody chromatograficzne łaczone sa $z$ analizami spektrometrycznymi. Podobnie jak w technice ESI/MS, pochodne tyrozyny poddawane sa jonizacji, ułatwiajacej późniejszy rozdział w spektrometrze, w którym sa dzielone ze względu na masę $\mathrm{i}$ ładunek (GAUT i współaut. 2002).

\section{Bromotyrozyna}

Bromotyrozyna powstaje w organizmie w wyniku działania silnego utleniacza, kwasu bromawego, na tyrozynę. Kwas bromawy jest syntetyzowany w katalizowanej przez mieloperoksydazę reakcji nadtlenku wodoru $z$ jonami bromku. Powstaje w organizmie $\mathrm{w}$ celu obrony przed patogenami, jednak w ostatnich badaniach stwierdzono dużą rolę tego zwiąku w tworzeniu uszkodzeń komórkowych. Zniszczenia wywołane obecnościa kwasu bromawego dotycza głównie białek, lipidów, węglowodanów, DNA i aminokwasów (PATTISON i DAVIES 2004). Modyfikacje białek indukowane przez kwas bromawy obserwowane sa w takich schorzeniach jak: reakcje alergiczne, infekcje (głownie pasożytnicze), astma i procesy nowotworzenia (WU i współaut. 1999).

Bromotyrozynę wykrywa się metodami podobnymi, jak detekcji chlorotyrozyny. Zaliczamy do nich różne rodzaje chromatografii: cieczowa, wysokosprawna cieczowa i gazowa, zwykle w połączeniu ze spektrometria mas (DALLE-DONNE i współaut. 2005).

\section{Sulfotlenek metioniny}

Reaktywne formy tlenu powoduja przekształcanie reszt metioniny w sulfotlenek metioniny lub pochodne sulfonu metioninowego (STADTMAN i LEVINE 2003). Reszty metioniny sa łatwo utlenianie i często znajdują się w pobliżu miejsc aktywnych enzymów, chroniąc je przed szkodliwym działaniem stresu oksydacyjnego. Dzięki temu, że sa utlenianie w pierwszej kolejności, chronia inne aminokwasy struktury białka przed utlenieniem i utrata funkcji (SocHASKI i współaut. 2001). Sulfotlenek metioniny powstaje także w reakcji nadtlenku wodoru $\mathrm{z}$ alkilowodoronadtlenkami. Utleniona metionina jest jednym $z$ markerów stresu oksydacyjnego. Jednak ze względu na obecność w organizmie reduktaz naprawiających uszkodzenia białek oraz brak przeciwciał mogacych wykryć sulfotlenek metioniny, jej detekcja jest dosyć trudna (SHACTER 2000).

Pomiaru sulfotlenku metioniny w próbkach in vitro dokonuje się przez rozszczepienie białek bromocyjanem (SHACTER 2000) i analizę przy pomocy HPLC. Nowa technika w badaniu sulfotlenków metioniny jest hydroliza próbek za pomoca kwasu metanosulfonowego (MSA). Technika ta polega na umieszczeniu próbek na kationowymiennej kolumnie, umożliwiającej oddzielenie MSA z aminokwasów, oraz rozdział aminokwasów metoda jonowej chromatografii gazowej połaczonej ze spektrometria mas (SOCHASKI i współaut. 2001).

\section{Dityrozyna}

W warunkach stresu oksydacyjnego dochodzi do utleniania całego łańcucha białkowego lub wybranych reszt aminokwasowych, które to $z$ kolei moga się ze sobą łączyć kowalencyjnymi wiąaniami krzyżowymi. W taki sposób tworzy się dityrozyna, powstajaca $z$ dwóch reszt tyrozynowych (STADTMAN i LEVINE 2003). Poza stresem oksydacyjnym, źródłem dityrozyny może być promieniowanie UV, proces starzenia, wodoronadtlenki lipidów, a także peroksydazy (GIULIVI i współaut. 2003).

Dityrozynę powszechnie wykrywa się za pomoca analizy HPLC $z$ użyciem diod UV lub znaczników fluorescencyjnych. (GIULIVI i współaut. 2003).

\section{Oksohistydyna}

Histydyna jest jednym $z$ aminokwasów narażonych na utlenianie $\mathrm{w}$ reakcjach $z$ metalami, co daje możliwość oceny stresu oksydacyjnego spowodowanego obecnościa metali (UCHIDA i KAWAKISHI 1993). Głównym produktem utleniania histydyny jest 2-oksohistydyna, jednak jej otrzymywanie w warunkach in vitro jest utrudnione. $\mathrm{W}$ reakcji $\mathrm{z}$ niektórymi metalami, np. jonami miedzi i cynku, oraz w obecności nadtlenku wodoru histydyna przekształca się w oksohistydynę. Natomiast jednoczesna reakcja histydyny $z$ jonami $\mathrm{Cu}^{2+} \mathrm{i}$ $\mathrm{H}_{2} \mathrm{O}_{2}$ powoduje powstanie asparaginy i kwasu asparaginowego, tak więc, aby otrzymać w tej reakcji oksohistydynę wymagana jest obecność askorbinianu (SCHÖNEICH 2000). Cu i askorbinian wsytępujac razem, stanowia systemem generujacy syntezę wolnych rodników. Po dodaniu askorbinianu następuje nasilenie syntezy wolnych rodników, pomijany jest etap powstawania kwasu asparaginowego i asparaginy, a histydyna utleniania jest do oksohistydyny.

Analiza asparaginy jako markera zmodyfikowanych białek nie jest możliwa, ponie- 
waż po hydrolizie kwasowej jest wykrywana jako asparaginian. Dlatego też markerem utleniania histydyny jest jedynie oksohistydyna (UCHIDA i KAWAKISHI 1993). Kwas asparaginowy jako aminokwas oraz jego amid, asparagina, sa naturalnymi składnikami białek. W momencie gdy histydyna utlenia się do kwasu asparaginowego, jego wykrycie może zostać zinterpretowane, że stanowi on fizjologiczny element białka, a nie jest markerem jego oksydacji, co $z$ kolei może zaniżyć faktyczny poziom oksydacyjnych uszkodzeń histydyny. Stąd też markerem utleniania histydyny może być tylko 2-oksohistydyna, która fizjologicznie w białku występować nie powinna.

2-oksohistydyna może być wykrywana za pomoca tradycyjnych metod analizy aminokwasów oraz metod spektrometrycznych, np. technika MALDI (ang. matrix-assisted laser desorption/ionization), łaczacca jonizacje próbki z późniejsza analiza jej masy w spektrometrze. Do identyfikacji wykorzystuję się także metodę ESI (DALLE-DONNE i współaut. 2005). Oksohistydynę można wykryć także przy pomocy metody chromatografii cieczowej w połaczeniu ze spektroskopia mas (ang. liquid chromatography-mass spectrometry, LC-MS) oraz spektroskopii magnetycznego rezonansu jadrowego (ang. nuclear magnetic resonance spectroscopy, NMR). Obecnie brak jest jednak metod specyficznych dla oksohistydyny; w dalszym ciagu trwaja badania nad przeciwciałami i białkami pozwalającymi wykrywać addukty histydyny (HUANG i współaut. 2015).

\section{Zaawansowane produkty utleniania białek}

Zaawansowane produkty utleniania bialek (AOPP) stanowia agregaty, fragmenty lub pochodne oksydacyjnie zmienionej albuminy, fibrynogenu lub lipoprotein. Pod względem struktury i właściwości biologicznych sa podobne do zaawansowanych produktów glikacji białek (AGE), sa wiazane przez ten sam receptor $i$ wywołuja te same choroby. AOPP powstaja pod wpływem stresu oksydacyjnego wywoływanego głównie przez reaktywne formy tlenu. Ich budowa nie jest do końca poznana. Wiadomo, że cząsteczki AOPP zawieraja dityrozyne, grupy karbonylowe, a także zmodyfikowane reszty tyrozyny, tryptofanu, lizyny, argininy i aminokwasów zawierajacych siarkę. Występują one u osób zdrowych, jednak w dużo niższych ilościach niż u osób chorych czy starszych, bowiem ich ilość wzrasta $z$ wiekiem (PIWOWAR 2000).

AOPP można wykryć przy użyciu wielu metod spektrofotometrycznych i chromatograficznych, które pozwalają także określić dokładne ich stężenie. Dzięki temu sa one wiarygodnymi markerami utleniania białek $\mathrm{w}$ organizmach. Istnieją także gotowe testy umożliwiajace ocenę stężenia AOPP w osoczu, surowicy krwi, moczu, płynie mózgowo-rdzeniowym, a także w lizatach i homogenatach tkankowych (PIWOWAR 2000).

Dostępna literatura wskazuje, iż największe znaczenie $w$ ocenie oksydacyjnego uszkodzenia białek wykazuja trwałe i proste do oznaczenia pochodne karbonylowe, 3-nitrotyrozyna i AOPP. To właśnie te modyfikacje białkowe najczęściej oznacza się u zwierząt laboratoryjnych narażonych na działanie czynników oksydacyjnych (ÓNODY i współaut. 2003, DOĞRU-ABBASOĞLU i współaut. 2007, PATEl i Kalia 2010, Amara i współaut. 2011, AZEVEDO i współaut. 2015).

\section{WPŁYW CZYNNIKÓW INDUKUJACYCH STRES OKSYDACYJNY U ZWIERZAT LABORATORYJNYCH NA ZAWARTOSĆ GRUP KARBONYLOWYCH W MATERIALE BIOLOGICZNYM}

W badaniach nad wpływem cynku na ilość pochodnych karbonylowych, jego niedobór, a także restrykcje kaloryczne powodowały wzrost stężenia uszkodzonych białek. Cynk zaangażowany jest w procesy zwiazane $z$ obrona antyoksydacyjna organizmu. Wchodzi w skład cytoplazmatycznej dysmutazy ponadtlenkowej (enzymu, który jest przeciwutleniaczem) i metalotionein (białek bogatych w reszty cysteinowych pełniace funkcje ochronne przed wolnymi rodnikami). Dlatego niedobór cynku przyczynia się do wzrostu oksydacyjnych uszkodzeń składników komórek (OTEIZA i współaut. 1995).

Wyniki przeprowadzonych badań wskazuja, że procesy starzenia organizmu przyczyniaja się do wzrostu zawartości pochodnych karbonylowych (PC) u szczurów. Obserwuje się bowiem istotna różnicę $\mathrm{w}$ ilości tych modyfikacji u zwierzat starszych i młodych. Czyni to pochodne karbonylowe wczesnymi markerami starzenia się i pozwala na dokonanie ogólnej oceny oksydacyjnych uszkodzeń białek (CAKATAY i współaut. 2003).

Przewlekłe spożywanie etanolu także powoduje wzrost zawartości pochodnych karbonylowych, zarówno w mitochondriach (o 0,39 ng/mg białek), jak i w cytozolu (o 0,17 $\mathrm{ng} / \mathrm{mg}$ białek). Wolne rodniki $\mathrm{z}$ rozkładu etanolu powstają w mitochondriach, skąd dyfunduja do cytoplazmy. Może to powodować większy wzrost uszkodzonych oksydacyjnie białek w mitochondriach. Dodatkowo, w cytoplazmie komórek wątroby występuje enzym katalaza, rozkładający $\mathrm{H}_{2} \mathrm{O}_{2}$, którego brak w mitochondriach wattroby. Obecność tego enzymu może stanowić dodatkowa ochronę dla białek cytoplazmy (BAILEY i współaut. 2001). 
Co ciekawe, ograniczenie podaży białka w diecie powoduje zmniejszenie akumulacji uszkodzonych białek w wyniku stresu oksydacyjnego wywołanego napromieniowywaniem. Podobne efekty uzyskiwane sa w wyniku diet $z$ restrykcja kaloryczna. Badania te potwierdzaja teorie, według której zmniejszenie spożycia białka nasila mechanizmy antyoksydacyjne, powoduje wzrost poziomu dysmutazy ponadtlenkowej oraz katalazy w mięśniach i wątrobie (YounGMAN i współaut. 1992).

Arszenik powoduje wzrost pochodnych karbonylowych oraz zaawansowanych produktów utleniania białek, ponieważ indukuje stres oksydacyjny w organizmie. Przyczynia się także do zmniejszenia ilości glutationu. W grupie kontrolnej jego ilość w 100

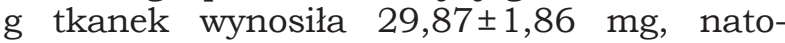
miast po podaniu arszeniku zmniejszyła się do $18,14 \pm 1,93 \mathrm{mg}$. Arszenik powoduje więc osłabienie mechanizmów obronnych przed wolnymi rodnikami (PATEL i KALIA 2010).

Dimetoat jest insektycydem stosowanym do ochrony upraw roślinnych, a podawany szczurom $z$ woda powodował powstawanie $\mathrm{w}$ mózgu reaktywnych form tlenu, uszkadzających białka. Jednak suplementacja diety selenem, który zapobiega chorobom mózgu, a także witaminą E, będaca antyoksydantem, zmniejsza ilość uszkodzeń. Niektóre szczury oprócz dimetoatu otrzymywały codzienne selen $(0,5 \mathrm{mg} / \mathrm{kg}$ pożywienia) lub witaminę E $(100 \mathrm{mg} / \mathrm{kg}$ pożywienia), natomiast trzecia grupa otrzymywała selen $\mathrm{i}$ witaminę $\mathrm{E}$. U szczurów, którym podawano dimetoat, ilość pochodnych karbonylowych wynosiła $42,907 \pm 5,560 \mu \mathrm{mol} / \mathrm{mg}$ białek, w grupie otrzymujaccej dodatkowo selen $21,909 \pm 4,573$ lub witaminę E 26,206 $\pm 3,043$, a w grupie otrzymujacej obydwie substancje $18,579 \pm 3,472$. Wyniki te świadcza o ochronnym działaniu witaminy $\mathrm{E}$ i selenu na tkanki mózgu, nawet w przypadku dostarczania substancji toksycznych (AMARA i współaut. 2011) (Tabela 1).

\section{WPEYW CZYNNIKÓW INDUKUJACYCH STRES OKSYDACYJNY U ZWIERZAT NA ZAWARTOŚ 3-NITROTYROZYNY W MATERIALE BIOLOGICZNYM}

Zawartość 3-nitrotyrozyny u myszy po podaniu paracetamolu rośnie po dwóch i czterech godzinach, natomiast po ośmiu godzinach ilość uszkodzonych białek zmniejsza się (IsHII i współaut. 2006).

Starzenie powoduje zwiększenie poziomu 3-nitrotyrozyny zarówno u szczurów młodych, jak i dorosłych, w stosunku do szczurów starszych. Dlatego nitrotyrozyna w mięśniach szkieletowych może być dobrym markerem uszkodzeń oksydacyjnych powodowanych starzeniem (CAKATAY i wspó1aut. 2003).

Po zakażeniu bakteria Escherichia coli w organizmach swinek morskich nastapił wzrost poziomu NO oraz reaktywnych form azotu (RNS), co doprowadziło do zwiększenia poziomu 3-nitrotyrozyny. Niektórym badanym osobnikom podawano witaminę $\mathrm{A} \mathrm{w}$ dawce $15000 \mathrm{IU} / \mathrm{kg}$ masy ciała przez $7 \mathrm{dni}$ przed zakażeniem. W grupie tej nie wykryto nitrotyrozyny (TÜRKÖZKAN i współaut. 2005). Oznacza to, że witamina A hamuje indukcję nitrotyrozyny i chroni komórki przed uszkodzeniami. Nie jest pewne, czy witamina A hamuje tworzenie RNS, czy raczej dochodzi do powstania RNS, które sa bardzo szybko neutralizowane przez witaminę A (drobnocząsteczkowy antyoksydant).

Narażenie myszy na benzen podnosi poziom nitrowania reszt tyrozyny, jednak tylko do dawki ok. $200 \mathrm{mg} / \mathrm{kg}$ masy ciała. Przy $400 \mathrm{mg}$ poziom uszkodzeń maleje. Może być to zwiazane $z$ mniejsza pula powstajacych wolnych rodników lub nasyceniem metabolizmu benzenu (CHEN i współaut. 2005).

Lipopolisachardy (LPS) powoduje w organizmie stan prooksydacyjny, zwłaszcza u szczurów $z$ marskością wątroby. W omawianym badaniu, u wszystkich grup szczurów oznaczono poziom przeciwutleniającej oksygenazy hemowej (HO-1), enzymu, który rozkłada hem. Najniższy poziom tego enzymu odnotowano u szczurów $z$ marskościa, a najwyższy u szczurów $z$ marskością, którym podawano LPS. U zdrowych osobników poziom HO-1 był również wyższy, zwłaszcza u tych, którym podano LPS. Wyniki badań wskazuja na zwiększenie stresu oksydacyjnego $u$ szczurów $z$ marskościa przyjmujacych LPS oraz dużo wyższe stężenie HO-1, które może być mechanizmem obronnym przed wolnymi rodnikami (DoĞRU-ABBASOĞLU i współaut. 2007).

Niedobór apolipoproteiny E powoduje hipercholesterolemię oraz podwyższenie poziomu lipoprotein o niskiej i pośredniej gęstości. Przyczynia się do wzrostu reaktywnych form tlenu i azotu, a tym samym do znacznego wzrostu ilości 3-nitrotyrozyny w tkance nerwowej badanych myszy (MATTHEws i BEAL 1996). Wpływ hipercholesterolemii na uszkodzenia białek wskazują również badania wykonane na szczurach. Hiperlipidemia indukowana była wysoka zawartościa cholesterolu w diecie. Uzyskane wyniki świadcza o zwiększonej produkcji reaktywnych form tlenu w układzie naczyniowym, przyczyniajacych się do zwiększenia stresu oksydacyjnego i uszkodzeń białek (ÓNODY i wspołaut. 2003) (Tabela 2). 
Tabela 1. Wpływ czynników indukujących stres oksydacyjny u zwierząt laboratoryjnych na zawartość grup karbonylowych w materiale biologicznym.

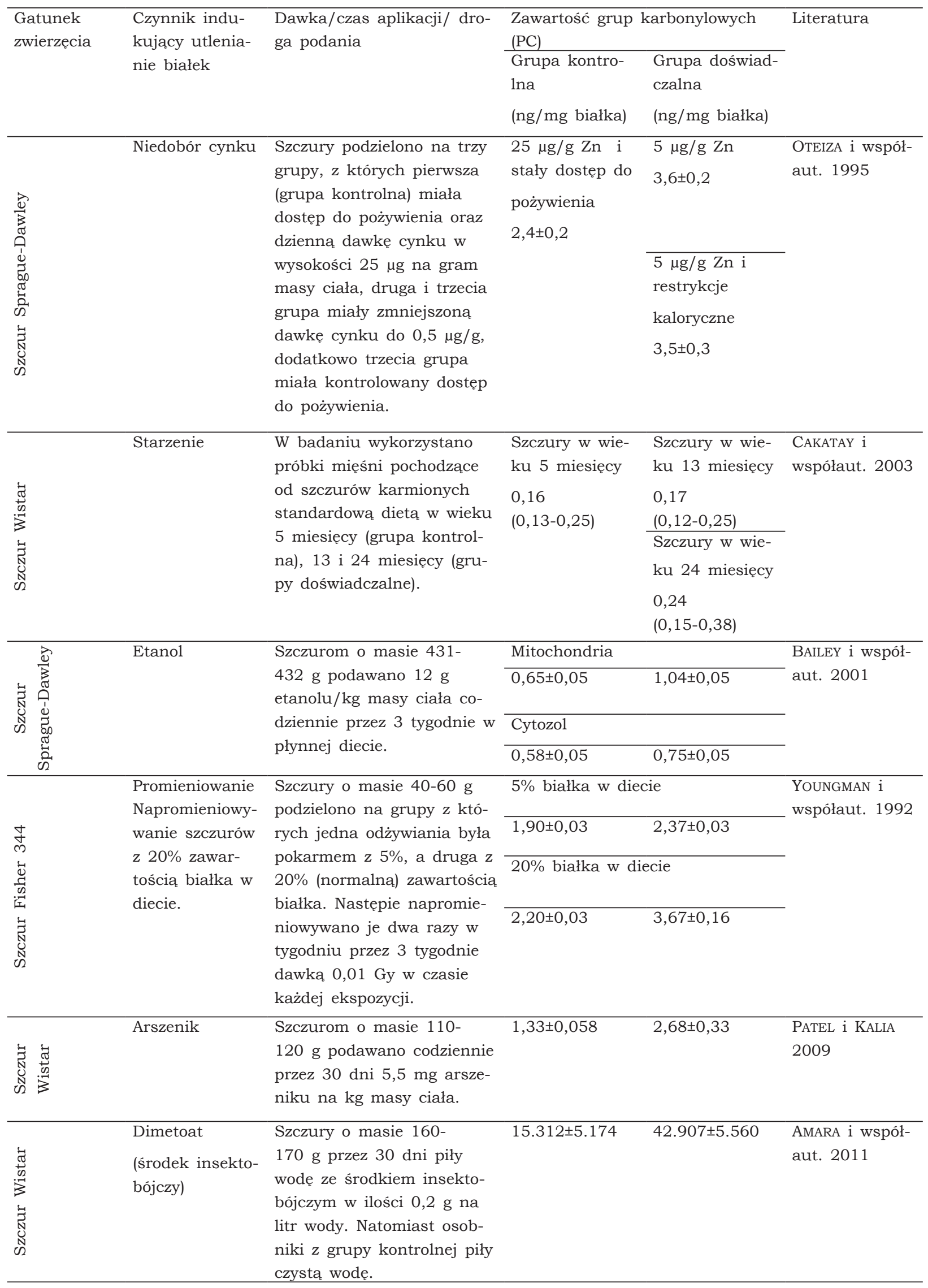


Tabela 2. Wpływ czynników indukujących stres oksydacyjny u zwierząt na zawartość 3-nitrotyrozyny $\mathrm{w}$ materiale biologicznym.

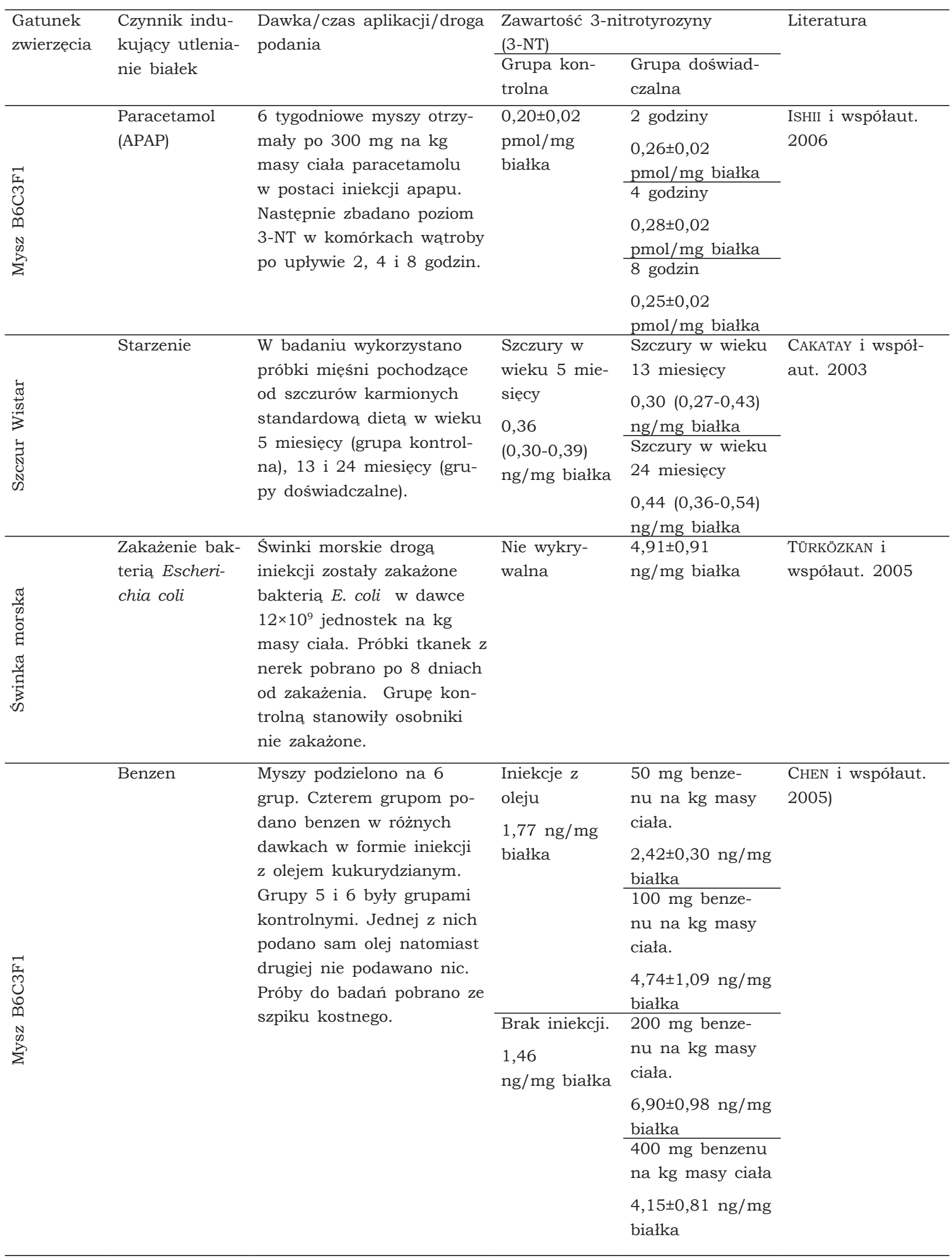




\begin{tabular}{|c|c|c|c|c|c|}
\hline 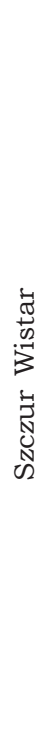 & $\begin{array}{l}\text { Marskość wa- } \\
\text { troby }\end{array}$ & $\begin{array}{l}\text { Szczury podzielono na } 4 \\
\text { grupy. } 1 \text { grupa to próba } \\
\text { kontrolna. Szczury z } 2 \text { gru- } \\
\text { py dostały w postaci iniek- } \\
\text { cji lipopolisacharyd(LPS) E. } \\
\text { coli w dawce } 5 \text {-mg/kg masy } \\
\text { ciała. Szczury z grup } 3 \text { i } \\
4 \text { dostawały wraz z woda } \\
\text { codziennie przez } 3 \text { miesiące } \\
\text { ok. 10mg tioacetoamidu w } \\
\text { celu wywołania marskości } \\
\text { watroby. Dodatkowo szczu- } \\
\text { ry z grupy } 4 \text { dostawały } \\
\text { lipopolisachardy w takiej } \\
\text { samej dawce jak osobniki } \\
\text { z grupy } 2 \text {. Próbki osocza } \\
\text { pobrano } 6 \text { godzin po poda- } \\
\text { niu LPS. }\end{array}$ & $6,05 \mathrm{nmol} / \mathrm{L}$ & $\begin{array}{l}\text { Grupa } 3 \mathrm{z} \text { mar- } \\
\text { skością } \\
6,5 \mathrm{nmol} / \mathrm{L}\end{array}$ & $\begin{array}{l}\text { DoĞRU-ABBASOĞLU } \\
\text { i współaut. } 2007\end{array}$ \\
\hline $\begin{array}{l}\hat{1} \\
0 \\
N \\
N \\
0 \\
\sum\end{array}$ & $\begin{array}{l}\text { Niedobór apoli- } \\
\text { poproteiny E }\end{array}$ & $\begin{array}{l}\text { Grupe kontrolna stano- } \\
\text { wiły myszy laboratoryjne } \\
\text { z prawidłowym poziomem } \\
\text { apolipoproteiny- E (Apo-E) } \\
\text { Myszy z niedoborem Apo-E } \\
\text { otrzymano w wyniku zmian } \\
\text { genetycznych w komórkach } \\
\text { macierzystych embrional- } \\
\text { nych myszy. } \\
\text { Po } 60 \text { dniach od narodzin } \\
\text { myszy uśmiercono i pobra- } \\
\text { no tkanki mózgu, zestawio- } \\
\text { no wyniki, a następnie po- } \\
\text { równano wszystkie próbki. }\end{array}$ & $\begin{array}{l}18,2 \pm 1,1 \\
* 1000 / \\
\text { tyrozyna }\end{array}$ & $\begin{array}{l}25,6 \pm 1,3 \\
* 1000 / \text { tyrozyna }\end{array}$ & $\begin{array}{l}\text { MATTHEWS i BEAL } \\
1996\end{array}$ \\
\hline 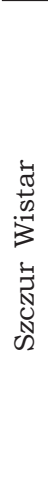 & $\begin{array}{l}\text { Indukowana } \\
\text { hiperlipidemia }\end{array}$ & $\begin{array}{l}\text { Szczury podzielono na dwie } \\
\text { grupy. Grupę kontrolną } \\
\text { przez } 8 \text { tygodni karmio- } \\
\text { no standardowa karmą, } \\
\text { natomiast doświadczalną } \\
\text { karma wzbogaconą w } 2 \% \\
\text { cholesterolu. Szczurom } \\
\text { dwa razy przed pobraniem } \\
\text { tkanek ( } 24 \mathrm{~h} \text { i } 1 \mathrm{~h} \text { ) podano } \\
\text { dootrzewnowo po } 20 \mu \text { mol/ } \\
\text { kg FeTPPS katalizatora roz- } \\
\text { kładu ONOO-. }\end{array}$ & $18 \mathrm{nmol} / \mathrm{L}$ & $31 \mathrm{nmol} / \mathrm{L}$ & $\begin{array}{l}\text { ÓNODY i wspołaut. } \\
2003\end{array}$ \\
\hline
\end{tabular}

WPEYW CZYNNIKÓW INDUKUJACYCH STRES OKSYDACYJNY U ZWIERZAT LABORATORYJNYCH NA ZAWARTOSĆ OKSYDACYJNIE ZMIENIONEJ ALBUMINY W MATERIALE BIOLOGICZNYM

Wszystkie badane zakażenia u szczurów powoduja wzrost zaawansowanych produktów utleniania białek. Zakażenie pierwotniakiem Blastocystis hominis powoduje wzrost oksydacyjnie zmienionej albuminy (AOPP) zarówno we krwi, jak i w moczu badanych szczurów. Dzięki temu markery uszkodzeń można łatwiej wykrywać ze względu na łatwość pozyskanie moczu od badanych szczurów (CHANDRAMATHI i współaut. 2009). U szczurów zainfeksowanych drożdżakiem Cryptococcus neoformans poziom AOPP rośnie zarówno 10 dni po zakażeniu, jak i 20 dni później. Wzrost ten może być związany 
Tabela 3. Wpływ czynników indukujących stres oksydacyjny u zwierząt laboratoryjnych na zawartość AOPP (oksydacyjnie zmienionej albuminy) w materiale biologicznym.

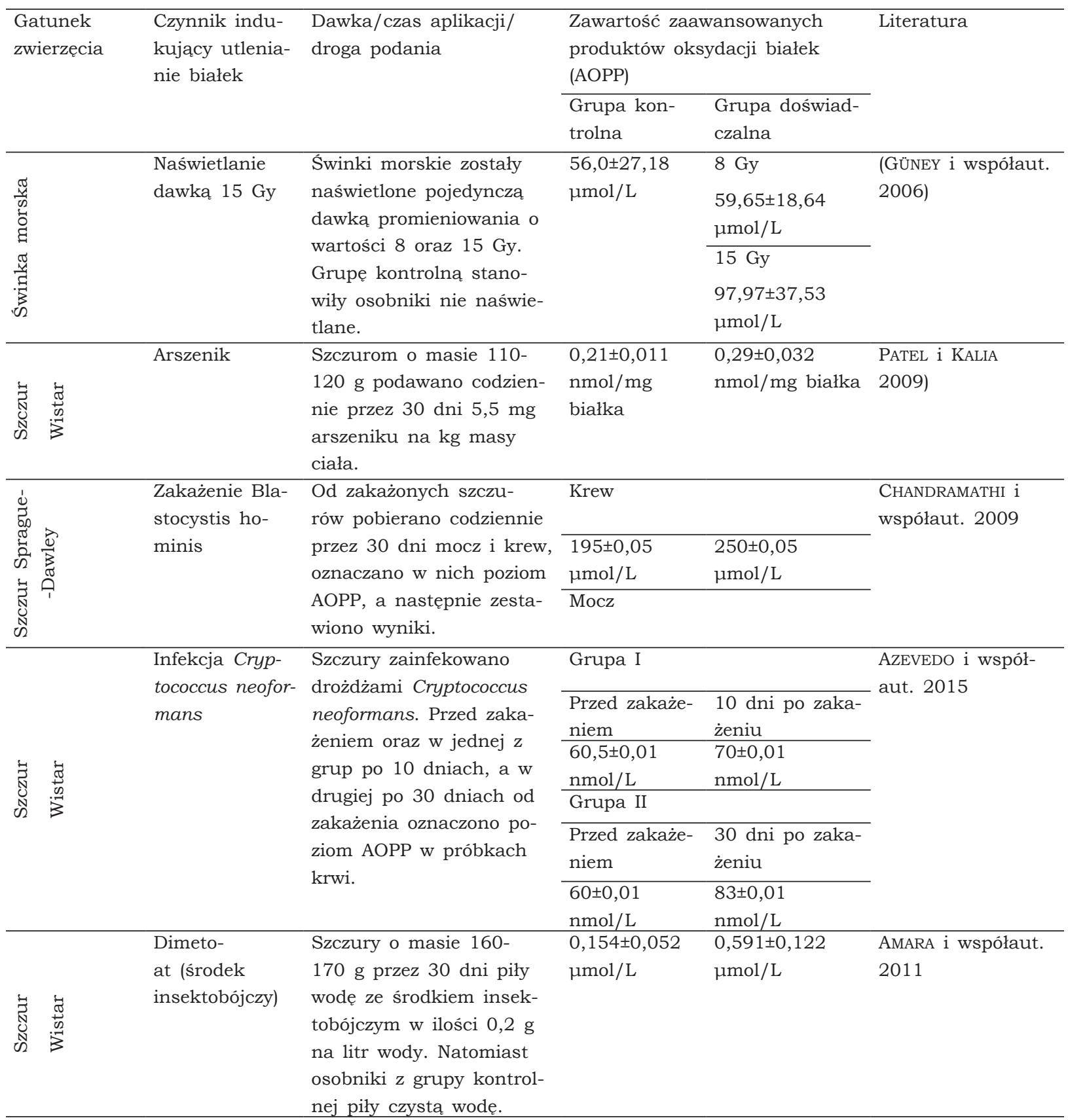

z reakcja zapalna organizmu i zwiększona synteza NO. W badaniu oznaczono również poziomy enzymów bedacych markerami stanu zapalnego: acetylocholinoesterazy (AChE) i butyrylocholinoesterazy (BChE); poziom AChE wzrósł, natomiast $\mathrm{BChE}$ spadł. Wyniki te wskazuja na wzrost stanu zapalnego, wzmożonej syntezy immunoglobulin i NO (AZEVEDO i współaut. 2015).

Promieniowanie generuje w organizmie reaktywne formy tlenu, powodujace uszkodzenia komórek i procesy kancerogenezy. W badaniu wpływu promieniowania na świn- ki morskie, wzrost AOPP zależał od dawki promieniowania. Określono również poziom antyoksydantów selenu i witaminy $\mathrm{E}$, które powinny chronić składniki komórek przed utlenianiem. Po 24 godzinach od naświetlania poziom tych związków nie zmienił się. Może to świadczyć o tym, że naświetlanie powoduje wahania poziomów antyoksydantów dopiero po upływie pewnego czasu (GÜNEY i współaut. 2006).

Arszenik, podobnie jak pochodne karbonylowe, powodował wzrost AOPP, ze względu 
na osłabienie mechanizmów antyoksydacyjnych organizmu (PATEL i KALIA 2010).

Dimetoat powodował znaczacy wzrost AOPP $w$ organizmach szczurów. Tak jak w przypadku pochodnych karbonylowych, zmierzono również ilość AOPP w przypadku zatrucia organizmu dimetoatem i dostarczenia antyoksydantów. U osobników, którym podawano jedynie insektycyd, poziom AOPP wynosił 0,591 $\pm 0,122 \mu \mathrm{mol} / \mathrm{mg}$ białka, dodatek selenu obniżał ten poziom do 0,188 \pm 0,034 , natomiast $\mathrm{w}$ obecności witaminy $\mathrm{E}$ wartość ta wynosiła 0,189 $\pm 0,053$. Połaczenie obydwu substancji zmniejszało ilość AOPP do $0,155 \pm 0,033 \mu \mathrm{mol} / \mathrm{mg}$ białka (AMARA i współaut. 2011) (Tabela 3).

\section{PODSUMOWANIE}

Stres oksydacyjny powoduje utlenianie w komórkach zwiazków takich jak białka, lipidy i DNA. Do oceny jego nasilenia wykorzystuje się różnorodne biomarkery. Do najtrwalszych należą markery białkowe. Wśród wielu takich wskaźników największym uznaniem ciesza się te, które są specyficzne dla badanej tkanki oraz najprostsze do oznaczenia: 3-nitrotyrozyna (3-NT), zawansowane produkty utleniania białek (AOPP), oraz pochodne karbonylowe (PC). Możliwość wykrywania tych modyfikacji umożliwia ocenę nasilenia stresu oksydacyjnego w organizmie, a także pomaga diagnozować wiele chorób i określać stan ich zaawansowania.

Wyniki badań wskazują, że zawartość biomarkerów oksydacyjnych uszkodzeń białek w ustroju wyraźnie wzrasta w odpowiedzi na stres oksydacyjny, wywołany takimi czynnikami jak niewłaściwa dieta, niedobór mikroelementów, zatrucie substancjami toksycznymi, infekcje czy starzenie się organizmu.

\section{Streszczenie}

Przewaga procesów prooksydacyjnych w organizmie skutkuje wystapieniem stresu oksydacyjnego objawiajacego się m.in. utlenianiem białek. Bezpośrednia analiza ilości reaktywnych form tlenu i azotu jest zadaniem bardzo trudnym, dlatego $\mathrm{w}$ ocenie nasilenia stresu oksydacyjnego częściej wykorzystuje się markery uszkodzeń, powstające $\mathrm{w}$ wyniku reakcji wolnych rodników $z$ białkami. Sa one o wiele trwalsze, a przez to łatwiejsze do analizy. Wśród najważniejszych biomarkerów oksydacyjnych uszkodzeń białek wyróżnia się pochodne karbonylowe, 3-nitrotyrozynę, S-nitrotriazole, kynureninę, 3-chlorotyrozynę, bromotyrozynę, sulfotlenek metioniny, dityrozynę, oksohistydynę oraz tzw. zaawansowane produkty oksydacji białek (AOPP).

W ocenie oksydacyjnych uszkodzeń białek u zwierzat laboratoryjnych najlepiej sprawdzaja się pochodne karbonylowe, 3-nitrotyrozyna i AOPP. Ich zawartość w ustroju wyraźnie wzrasta w odpowiedzi na stres oksydacyjny wywołany takimi czynnikami, jak: niewłaściwa dieta, niedobór mikroelementów, zatrucie substancjami toksycznymi, infekcje czy starzenie.

\section{LITERATURA}

AMARA I. B., SOUdANI N., HAKIM A., TROUdI A., ZEGHAL K. M., BOUdAWARA T., ZEGHAL N., 2011. Selenium and vitamin $E$, natural antioxidants, protect rat cerebral cortex against dimethoate-induced neurotoxicity. Pesticide Biochem. Physiol. 101, 165-174.

Azevedo M. I., Ferreiro L., Da Silva A. S., Tonin A. A., Thorstenberg M. L., Catilhos L. G., FrançA R. T., LEAL D. B. R., DUARTE M. M. M. F., Lopes S. T. A., SANGoi M. B., MoresCO R. N., Fighera R., SANTURIO J. M., 2015. Cholinesteraze of rats experimentally infected by Cryptococcus neoformans: Relationship between inflammatory response and pathological findings. Pathol. Res. Practice 211, 851-857.

Bailey S. M., Patel V. B., Young T. A., Asayama K., CunNingham C. C., 2001. Chronic etanol consumption alters the glutathione/ glutathione peroxidase-1 system and protein oxidation status in rat liver. Clin. Exp. Res. 25, 726-732.

Çakatay U., TElci A., Kayali R., TeKeli F., AKçAY T., SIVAS A., 2003. Relation of aging with oxidative protein damage parameters in the rat skeletal muscle. Clin. Biochem. 36, 51-55.

CHANDRAMATHI S., SURESH K., ANITA Z. B., 2009. Comparative assessment of urinary oxidative indices in breast and colorectal cancer patients. J. Cancer Res. Clin. Oncol. 135, 319323.

Chapman A. L. P., Senthilmohan R., WinnterBOURN C. C., KeTtle A. J., 2000. Comparison of mono- and dichlorinated tyrosines with carbonyls for detection of hypochlorous. Acid Modif. Prot. 377, 95.

Chen K. M., El-Bayoumy K., Hosey J., CunningHAM J., Aliaga C., MELiKian A. A., 2005. Benzene increases protein- bound 3-nitrotyrosine in bone marrow of $B 6 C 3 F$, mice. Chem.- Biol. Interact. 156, 81-91.

Dalle-Donne I., Rossi R., GiUstarini D., MilzaNI A., COLOMBO R., 2003. Protein carbonyl groups as biomarkers of oxidative stress. Clin. Chim. Acta 329, 23-28.

DAlle-Donne I., SCALONI A., GiUSTARINI D., CAVArRa E., Tell G., Lungarella G., Colombo R., Rossi R., Milzani A., 2005. Protein as biomarkers of oxidative/ nitrosative stress in diseases: the contribution of redox proteomics. Mass Spectrom. Rev. 24, 55-99.

DOğRU-ABBASOğLU S., PARILDAR-KARPUZOğLU H., BALKAN J., AYKAç-TOKER G., UYSAL M., 2007. Nitrotyrosine formation and heme oxygenase1 expression in endotoxemic cirrhotic rats. Arch. Med. Res. 38, 28-33.

EHRENSHAFT M., DETERDING L. J., MASON R. P., 2015. Tripping up Trp: Modification of protein tryptophan residues by reactive oxygen species, modes of detection, and biological consequences. Free Rad. Med. 89, 220-228.

GauT J. P., Byun J., TRAN H. D., HeinecKe J. W., 2002. Artifact-free quantification of free 3-chlorotyrosine, 3-bromotyrosine, and 3-nitrotyrosine in human plasma by electron capture-negative chemical ionization gas chromatography mass spectrometry and liquid chromatography-electrospray ionization tandem mass spectrometry. Anal. Biochem. 300, 252-259.

Giulivi C., TRAASETH N. J., DAVIES J. A., 2003. Tyrosine oxidation products: analysis and biological relevance. Amino Acids 25, 227-231.

GRIMSRUD P. A., XIE H., GRIFFIN T. J., BERNLOHR D. A., 2008. Oxidative stress and covalent modification of protein with bioactive aldehydes. J. Biol. Chem. 283, 21837-21841. 
GÜNEY Y., TÜRKçÜ Ö.Ü., MERTOğLU Ö., BILGIHAN A., HiçSÖNMEZ A., ANDRIEU M. N., KURTMAN C., 2006. Serum AOPP, selenium and vitamin $E$ levels after irradiation. Turk. J. Cancer 36, 19-21.

HuANG C, LIU Y., TAI H., 2015. Synthesis of peptides containing 2-oxohistidine residues and their characterization by liquid chromatography-tandem mass spectrometry. J. Peptide Sci. 21, 114-119.

ISHII Y., IIJIMA M., UMEMURA T., NISHIKAWA A., IWASAKI Y., ITO R., SAito K., Hirose M., NAKAZAWA H., 2006. Determination of nitrotyrosine and tyrosine by high-performance liquid chromatography with tandem mass-spectrometry and immunohistochemical analysis in livers of mice administered acetaminophen. J. Pharmaceut. Biomed. Anal. 41, 1325-1331.

KAROLKIEWICZ J., 2011. Wpływ stresu oksydacyjnego na strukture $i$ funkcje komórek oraz konsekwencje wynikajace $z$ uszkodzeń wolnorodnikowych - zwiazek $z$ procesami starzenia. Gerontologia Polska 19, 59-65.

KoŁODZIEJCZYK J., 2010. 3-nitrotyrozyna- marker stresu oksydacyjnego in vitro $i$ in vivo. J. Lab. Diagnost. 46, 141-145.

MatTHEWS R. T., Flint BEAL M., 1996. Increased 3-nitrotyrosine in brains of Apo E- deficient mice. Brain Res. 718, 181-184.

Oteiza P. I., Olin K. L., Fraga C. G., Keen C. L., 1995. Zinc deficiency causes oxidative damage to proteins, lipids and DNA in rat testes. J. Nutrit. 95, 823-828.

ÓNODY A., CSONKA C., GIRICZ Z., FERDINANDY P. 2003. Hyperlipidemia induced by a cholesterol-rich diet leads to enhanced peroxynitrite formation in rat heart. Cardiovasc. Res. 58, 663670

PATEL H. V., KALIA K., 2010. Sub-chronic arsenic exposure aggravates nephrotoxicity in experimental diabetic rats. Ind. J. Exp. Biol. 48, 762-768.

PATTISON D. I., DAVIES M. J., 2004. Kinetic anal ysis of the reactions of hypobromous acid with protein components: implications for cellular damage and use of 3-bromotyrosine as a marker of oxidative stress. Biochemistry 43 , 4799, 4800

PIWOWAR A., 2010. Zaawansowane produkty utleniania białek. Czéść I. Mechanizm powstawa- nia, struktura $i$ właściwości. Polski Merkuriusz Lekarski 28, 166-169.

PONCZEK M.B., WACHOWICZ B., 2005. Oddziaływanie reaktywnych form tlenu $i$ azotu $z$ biakkami. Post. Biochem. 51, 140-144.

SCHÖNEICH C., 2000. Mechanisms of metal-catalyzed oxidation of histidine to 2-oxo-histidine in peptides and proteins. J. Pharmaceut. Biomed. Anal. 21, 1093-1094.

SHACTER E., 2000. Quantification and significance of protein oxidation in biological samples. Drug Metab. Rev. 32, 307-326.

SOCHASKI M. A., JENKINS A. J., LyONS T. J., THORPE S. R., BAYNES J. W., 2001. Isotope dilution gas chromatography/ mass spectrometry method for the determination of methionine sulfoxide in protein. Analyt. Chem. 73, 46624667.

STADTMAN E. R., LEVINE R. L., 2003. Free radical-mediated oxidation of free amino acids and amino acid residues in proteins. Amino Acids 25, 207-218.

SZUBA A., WOJTASZEK P., 2010. Modyfikacje strukturalne białek wywołane przez tlenek azotu. Post. Biochem. 56, 107-112.

TÜrköZkan N., Seven I., ERDAMaR H., Cimen B. 2005. Effect of vitamin A pretreatment on Escherichia coli- induced lipid peroxidation and level of 3-nitrotyrosine in kidney of guinea pig. Mol. Cell. Biochem. 278, 33-37.

UCHIDA K., KAWAKISHI S., 1993. 2-Oxo-histidine as a novel biological marker for oxidativelymodified proteins. Fed. Europ. Biochem. Soc. 332, 208-210.

WŁODEK L., ICIEK M., 2003. S-tiolacja białek jako mechanizm antyoksydacyjnej regulacji. Post. Biochem. 49, 78-79.

Wu W., Chen Y., Avignon A., HaZen S. L., 1999. 3-Bromotyrosine and 3,5-Dibromotyrosine are major products of protein oxidation by eosinophil peroxidase: potential markers for eosinophil - dependent tissue injury in vivo. Biochemistry 38, 3539-3548.

YOUNGMAN L. D., PARK J.-Y. K., AMES B. N., 1992. Protein oxidation associated with aging is reduced by dietary restriction of protein or calories. Med. Sci. 89, 9112-9116. 
KOSMOS Vol. 67, 2, 347-359, 2018

\author{
Katarzyna OGNiK, Ewelina ChOlEwińska
}

Department of Biochemistry and Toxicology, Faculty of Biology, Animal Sciences and Bioeconomy, University of Life Sciences in Lublin, 13 Akademicka Str., 20-950 Lublin,E-mail: kasiaognik@poczta.fm

\title{
BIOMARKERS OF PROTEINS OXIDATIVE DAMAGE
}

\section{Summary}

The prevalence of prooxidative processes in the body is associated with development of oxidative stress, one of the symptoms of which is oxidation of proteins. Direct analysis of the amount of reactive forms of oxygen and nitrogen is a very difficult task. Therefore, in assessing the severity of oxidative stress, markers generated by free radical reactions with proteins are often used. They are much more durable and thus easier to analyze. The most important biomarkers of oxidative damage of proteins are protein carbonyl compounds, 3-nitrothyrosine, S-nitrotriazoles, kynurenine, 3-chlorothyrozine, bromothyroxine, methionine sulfoxide, dithyrosine, oxohistidine and and so called advanced oxidation protein products (AOPP).

Protein carbonyls, 3-nitrotyrosine and AOPP are the best indicators for evaluating of oxidative damage of proteins in laboratory animals. Their content in the body is clearly increasing in response to oxidative stress caused by such factors as improper diet, micronutrient deficiencies, toxic poisoning, infections or aging.

Key words: 3-nitrotyrosine, advanced oxidation protein products, biomarker, oxidative stress, protein, protein carbonyl 